ELORE (ISSN 1456-3010), vol. $16-2 / 2009$.

Julkaisija: Suomen Kansantietouden Tutkijain Seura ry.

[http://www.elore.fi/arkisto/2_09/kirjallisuus_hamalainen_2_09.pdf]

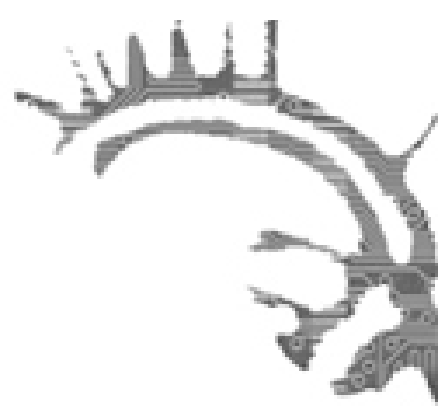

\title{
KiRJA-ARVIO:
}

\section{TehdasyhteisöN MONET UlOTTUVUUdeT}

Ahvenisto, Inkeri 2008: Tebdas yhdistäa ja erottaa. Verlassa 1880-luvulta 1960-luvulle. Bibliotheca Historica 118. Helsinki: SKS. 557 sivua.

\section{Tommi-Tapio Hämäläinen}

Suomalaisten tehdasyhteisöjen historiasta herää ehkä tavallisimmin mielikuvia karhean romanttisista työläiskasarmeista ja kylämäisistä asuinympäristöistä, joiden asujaimisto koostuu sosiaalisesti luokittuneista mutta yhteisöllisesti vastuullisista kansalaisista. Menneisyyden mielikuvien tehdas on liiketaloudellisen yrityksen lisäksi myös tuotantolaitos, joka jauhaa hyvinvointia ja turvallisuutta omalle rahvaanväellensä - kuten kansalliseepoksemme muinainen Sampo. Romanttisen kuvan mukaan tehdas pitää väestään huolta, väki elää symbioosissa tehtaansa kanssa ja perheet elävät arjessa rinta rinnan, toisiaan tukien. Tehdasyhteisöt on näin nähty usein kadonneen yhteisöllisyyden näyttämöinä. Vastakkaisena mielikuvana - mutta yhtä romanttisesti - menneisyyden tehdaskyliä on pidetty usein myös räiskyvien työtaisteluiden ja perhedraamojen näyttämöinä.

Inkeri Ahvenisto on pureutunut väitöskirjassaan siihen, minkälainen vuorovaikutus- ja riippuvuussuhteiden verkosto pohjoisessa Kymenlaaksossa sijainneessa Verlan pahvitehdasyhdyskunnassa aikoinaan kehittyi ja vallitsi. Missä määrin tehtaasta helposti mieleen nousevat stereotypiat saavat tukea todellisuudesta, ja miten oikea elämä lopulta poikkesi siitä kuvasta, mikä on jäänyt niin monien ihmisten muistoihin sekä käsityksiin. Ahveniston teoksesta muodostuukin erittäin monitasoinen ja sisällöllisesti runsas sukellus Verlan tehtaan vaiheisiin. 


\section{TOMMI-TAPio HÄMÄLÄINEN}

\section{TEHDASHISTORIIKKI TUTKIMUKSENA}

Kirjaa voi lähestyä hedelmällisesti niin mikrohistoriallisena yhteisötutkimuksena, kansatieteellisenä teoksena, kriittisenä yhteiskunta- ja sukupuolirakenteisiin pureutuvana tarkasteluna kuin talous- ja sosiaalihistoriallisena tutkimuksena. Teosta voi myös hyvin lukea Verlan kuvauksellisena historiikkina.

Kirjoittaja kertoo itse teoksen johdannossa, että hänen pyrkimyksenään ei ole ollut esittää menneisyyttä koskevia yleistyksiä ja yksinkertaistettuja malleja vaan kiinnittää huomiota menneisyyden moninaisuuteen ja ainutlaatuisuuteen. Hän lähestyy tätä esittämällä lukuisien arkistolähteiden ja esimerkkien kautta, miten tehtaan tuotannolliset ja yhteisön eri ryhmien inhimilliset intressit ovat limittyneet ja kietoutuneet toisiinsa yhteisessä arkisessa kanssakäymisessä. Ahvenisto on käyttänyt tutkimuksessaan rinnakkain runsasta asiakirja-aineistoa ja muistitietoaineistoa. Henkilökohtaisina muistelmina on hyödynnetty ensisijaisesti Verlassa 1997-2005 tehtyjä haastatteluja.

\section{IHMISIÄ TEHDASKYLÄSSÄ}

Kirjassa tarkastellaan tutkimuksen lähtökohtien ja Verlan syntyhistorian esittelyn jälkeen viittä pääteemaa: Millaisista ihmisistä Verlan väki koostui? Miten erilaiset työtehtävät ja muut henkilöstörakenteet yhdistivät ja erottivat yhteisön jäseniä? Millaisella otteella tehdas isännöi työväestöään? Miten työväenliike toimi Verlassa? Millaista sosiaalipolitiikkaa tehtaalla harjoitettiin?

Ahvenisto on ajoittanut Verlan tehdaskylän synnyn 1800-luvun loppuvuosikymmenille. Kyläyhteisö vakiintui tehtaan ympärille, kun Kuusankosken tehtaalla toiminut itävaltalainen paperimestari Gottlieb Kreidl osti vuonna 1881 paikalla toimineen puuhiomon useita pieniä tehtaita perustaneelta yrittäjä Hugo Neumanilta. Kreidl ryhtyi kehittämään hiomosta modernia tehdasta. Vaikka alkuvuodet olivatkin 1880-luvun laman kourissa hankalia, tuotanto alkoi kuitenkin pikku hiljaa kehittyä ja kylä sen ympärillä kasvaa.

Ahvenisto kartoittaa Verlan väestön rakennetta niin tehtaan perustamisvaiheen johtajien taustojen, toteuttavan tason työväestön koostumuksen kuin heidän perheidensäkin elämän tarkastelun kautta. Hän nostaa esiin myös sen, kuinka tällä pienellä paikkakunnalla oli suhteellisen syrjäisestä sijainnistaan huolimatta poikkeuksellisen vireät yhteydet suureen maailmaan. Verlan ensimmäinen teollisuusyrittäjä Hugo Neuman oli alun perin Oulun suomenruotsalaisia. Hän oli opiskellut teknillistä alaa muun muassa Zürichissä Sveitsissä ja omasi laajan kansainvälisen tuttavapiirin. Liikemies toi Verlaan sekä sosiaalisen verkostonsa että kansainvälistä tietotaitoa.

Kirjoittaja nostaa esiin, miten tehtaan perustajien alulle laittama ulospäin suuntautuva kehitys jatkui myös seuraavien omistajien ja johtajien aikana. Tehtaalle hankittiin sekä viimeisimmät tehokkaan teollisuuden edellyttämät innovaatiot että muut tekniikan keksinnöt - kuten puhelinlinja, joka saatiin käyttöön jo 1890-luvulla. Erityisesti tehtaan ylempiin tehtäviin, virkailijoiksi ja toimihenkilöiksi pyrittiin värväämään koulutettua ja kokenutta henkilöstöä. Myös tehtaan työnjohtajat tulivat valtaosin paikkakunnan 


\section{TEHDASTYÖN MONET ULOTTUVUUDET}

ulkopuolelta. Jälkeenpäin tehdyssä tarkastelussa voidaan havaita, että useat heistä jäivät seudulle loppuiäkseen. Suorittavan työn tekijöissä puolestaan oli sekä työn perässä muualta tulleita että Verlankosken paikallisseutujen alkuperäistä väestöä. Osa työläisistä viihtyi työssään lyhyen aikaa, osa jäi tehtaalle eläkkeelle jäämiseensä asti. Niistä, jotka jäivät, muodostui lopulta monenlaisin työ- ja perhekuntayhteyksin toisiinsa limittyvä ja verkostoituva kyläkunta. Kirjoittaja kuvaa myös haastatteluina keräämiensä muistelmien välityksellä muun muassa sitä, ketkä olivat mielestään "meitä verlalaisia", ketkä "muita".

\section{MITEN TYÖ YHDISTI JA EROTTI}

Kirjan toisena pääteemana Ahvenisto tarkastelee sitä, miten tehtaan erilaiset toimenkuvat, työtehtävät ja näiden haltijoiden keskuudessa kehittyneet pienyhteisöt jakoivat väkeä moniin erilaisiin hierarkiaportaisiin ja porukoihin. Koska yritys oli moderni teollisuuslaitos, tehtaalla oli varsinaisten työnjohtaja-työntekijähierarkioiden lisäksi myös useita erikoistyötehtäviä, jotka jakoivat väkeä rajatuiksi ammattikunniksi. Jo tehtaan tuotantopuolella työskenteli - vain muutamia esimerkkejä mainitakseni muun muassa sirkkelimiehiä, prässimiehiä, liippareita, kiillottajia, pakkareita sekä huoltohenkilöstöä. Kunkin ammatin edustajat tekivät töitä omien erikoistuneiden mestareidensa alaisuudessa. Kaikki tällaiset tehtävät olivat jo lähtökohtaisesti eritasoista ammattitaitoa edellyttäviä ja eriasteisesti arvostettuja. Tämä heijastui myös tehtaan väen henkilöhierarkioihin sekä henkilöstön tehtäväkohtaiseen pysyvyyteen.

Kuten oman aikansa yhteiskunnassa muutoinkin, myöskin Verlan tehtaassa vallitsi varsin selkeä sukupuolten välinen työnjako. Tämän ohella Ahvenisto huomioi tutkimuksessaan myös sen, miten tehtäväkohtainen sukupuolijakauma kehittyi ja muuttui Verlassakin aikojen saatossa, ainakin jossakin määrin. Kirjoittaja havainnoi, että eri sukupuolta edustavien työntekijöiden ammatillisista siirtymistä oli erotettavissa maatalousyhteiskunnan työnjakoa vastaava malli: erityisesti uudempina aikoina naiset saattoivat siirtyä tarvittaessa "miesten töihin" - mutta harvemmin toisin päin.

Kirjoittaja tarkastelee myös eri-ikäisten työntekijöiden tehtäväkohtaisia jakaumia, arvostuseroja sekä palkkaeroja seuraavia henkilöhierarkioita. Ahveniston lähtökohtana on, että kaikki nämä tekijät liittyivät siihen, millaisia yhteisyyden muotoja tehtaan elinpiirissä rakentui ja jäsentyi.

\section{TehtaAn IsÄLlinen OTE}

Ahveniston tutkimusotetta voidaan luonnehtia lempeän kriittiseksi. Hän ei kaihda nostaa esiin tehtaalla tapahtunutta vallankäyttöä ja eriarvoisuuksia - mutta tarkastelee tällaisia seikkojakin aina historiallisessa kontekstissa. Erilaisten vallankäyttöön liittyvien rakenteiden ja näiden tehtaanväelle tuottamien vaikutusten huomiointi ja pohdinta onkin eräs läpi teoksen kantava yleinen näkökulma. 


\section{TOMMI-TAPio HÄMÄLÄINEN}

Ahvenisto käsittelee tästä lähtökohdasta huomattavan perusteellisesti muun muassa tehtaan patruunan johdolla harjoitettua paternalistista työnantajapolitiikkaa. Tämän ohella hän huomioi kuitenkin myös tehtaan isäntäjohtoisen hallintomuodon toista puolta: sitä, miten työntekijöiden asumisesta, terveydenhuollosta ja lasten koulunkäynnistä pidettiin huolta. Oman lukunsa kirjassa on saanut myös tehtaalla vaikuttaneen työväenliikkeen toimintahistoria. Kirjoittaja nostaa työväenliikkeen vaiheita ja sen toiminnan keskeisiä piirteitä erityisesti suhteessa vuosien 1917-1918 tapahtumiin, sekä ennen että jälkeen sisällissodan vaikutusten.

Teoksen mittavimman yhtenäisen osion muodostaa luku, jossa Ahvenisto tarkastelee tehtaalla harjoitettua työnantajapolitiikkaa ybtiövetoisen byvinvointikapitalismin käsitteen kautta. Hän käsittelee työnantajan politiikan ulottuvuuksia ja käytäntöä muun muassa tehtaan sivistys- ja sosiaalitoiminnan sekä tehdasseudulla asuneiden perheiden arkielämän lähitarkastelun kautta. Ahveniston näkemys on, että eräs tehtaan työnantajapolitiikan keskeinen lähtökohta oli pyrkiä luomaan ja pitämään yhteisössä yllä erityistä tunneyhteisyyttä. Kirjoittaja nostaa myös esiin, miten työnantajan hyvinvointikapitalismin ohjelmat ja käytäntö kävivät yhteen työväestön omien aatteellisten tavoitteiden kanssa.

Teoksen viimeisten lukujen tutkimukselliset näkökulmat seuraavat samalla tehdasyhteisön ajallista historiaa, joten tutkimuksen viimeisissä osioissa tarkastellaan lähikuvassa myös tehtaan loppuvaiheita ja tuotantolaitoksen sulkemista - ja sitä, miten elämä jatkui Verlassa tehtaan lopettamisen jälkeenkin. Kirja muodostaa näin kokonaisuudessaan huomattavan laajan tutkimuksellisen kartoituksen erään suomalaisen tehdasyhteisön menneisyydestä, rakenteista ja inhimillisestä arjesta. Teos toimii samalla myös kaikessa mittavuudessaan varsin mallikelpoisesti Unescon maailmanperintökohteeksi valitun Verlan kuvauksellisena historiikkina.

Filosofian maisteri Tommi-Tapio Hämäläinen on folkloristiikan jatko-opiskelija Helsingin yliopiston kulttuurien tutkimuksen laitoksessa. 